\title{
Communicative Competence Formation of Future Officers in the Process of Foreign Language Training
}

\author{
Mykhaylo M. Kozyar ${ }^{1}$, Lidiia L. Nanivska², Oksana Ya. Romanyshyna ${ }^{3}$, Andriy M. Romanyshyn ${ }^{4} \&$ Yurii M. \\ Yakimets $^{5}$ \\ ${ }^{1}$ Department of Applied Psychology and Pedagogy, Institute of Psychology and Social Protection, Lviv State \\ University of Life Safety, Lviv, Ukraine \\ ${ }^{2}$ Department of Foreign Languages and Military Translation, Hetman Petro Sahaidachnyi National Army Academy, \\ Lviv, Ukraine \\ ${ }^{3}$ Department of Informatics and Its Teaching Methods, Ternopil Volodymyr Hnatyuk National Pedagogical \\ University, Ternopil, Ukraine \\ ${ }^{4}$ Department of Moral and Psychological Support for the Troops, National Academy of Land Forces named after \\ Hetman Peter Sahaidachny, Lviv, Ukraine \\ ${ }^{5}$ Automobile and Road College of the Lviv Polytechnic National University, Lviv, Ukraine \\ Correspondence: Lidiia L. Nanivska, Hetman Petro Sahaidachnyi National Army Academy, 32 Heroes of Maidan \\ street, Lviv, 79026, Ukraine.
}

Received: June 10, 2020

Accepted: August 3, 2020

Online Published: August 7, 2020

doi:10.5430/ijhe.v9n7p153

URL: https://doi.org/10.5430/ijhe.v9n7p153

\begin{abstract}
Modernization of the military system and its content has enhanced the value of the foreign language as a subject aimed at the formation of communicative competence of future officers. It mainly concerns a professional language, which is an obligatory part of the cadets' professional training. One of the main tasks of foreign language training of future officers is to form the communicative competency in the spheres of professional and situational communication as well as to learn new professional information from foreign sources. Based on the stated above, the author developed the methodology of forming communicative competence of future officers in the process of foreign language training with the active implementation of informational communicative technologies and computer means of teaching: the virtual reality, military-professional games, role play stimulators, and other software, within which a dialogue appeared. The last is regarded as an active message exchange between participants of the educational process or a user and the information system in real-time. The use of informational communicative technologies has enabled instant access to remoted module informational resources, synchronous (asynchronous) communication between subjects of the educational process. It has also provided new opportunities for testing, administration, and cooperation. The experimental usage of the author's methodology was implemented into the teaching process of the subject "Foreign language" based on the intercultural educational environment as a set of immersion, virtual, interactive, and discourse educational environments. The analysis of the obtained results and objective consideration of the dynamics of the changes in the formation of communicative competence of future officers have been done through the integrated test (targeted monitoring, a set of adapted tests application, an online survey, a questionnaire, case study, situational modelling, individual and group interviews) and methods of mathematical statistics. The conducted study has proved the efficiency of the author's methodology implementation based on the intercultural educational environment of higher military education establishments. The proposed methodology can be successfully used in the process of foreign language training of various specialists because its main strategic orientation is to form communicative competence and abilities for intercultural communication among students (cadets).
\end{abstract}

Keywords: foreign language training, communicative competence, future officers, intercultural educational environment (immersion, virtual, and interactive)

\section{Introduction}

Military professional training is mainly aimed at forming a set of special knowledge, skills, abilities, and qualities of future officers; at learning from the service experience and rules of professional behaviour, which provide the possibility of successful performance of military duties of a certain profession and a post (Bloshchynskyi, 2015a; 
2015b). However, in the modern era, the interdependence of countries and nations is growing; various aspects of human activities are internationalizing; the integrational process of international cooperation is becoming urgent (Besnier, 2013; Grin \& Faniko, 2012; Hošková-Mayerová, 2014). Development of military cooperation with foreign countries, organizations and conducting joint exercises and maneuverers, participation in peacekeeping operations, and partnership in military training cause the need in training such military specialists who are ready to adequate cooperation with representatives of other cultural communities (Koval, Polyezhayev \& Bezkhlibna, 2018; Mikkelson, York \& Arritola, 2015). Such conditions dictate the orientation of the educational policy of a higher military education establishment on the interconnection of a profession, culture, and a language; on the convergence of professional, military, social and cultural, foreign language education (Crouse, 2018; Robles, 2012; Umairah, 2014). This includes the formation of communicative competence, in particular foreign language one, among future officers. This competence should be based on values motivation and attitude to the language, intercultural communicative competence as an integrative professional and personal resource, learned linguistic, and extra-linguistic realia of the surrounding reality according to both specificity of information perception by modern cadets and implementation of innovative technologies.

The objective of foreign language training in higher military education establishments is to master a foreign language as a way of communication; to obtain professionally oriented communicative competence for further successful professional activity performance. Foreign language teaching of future officers is regarded as the aim of further professional development.

Successful formation of cadets' communicative competence in the context of military foreign language education can be reached by using various forms of activities and participation of all cadets in different events (Hackman \& Johnson, 2013); by the formation of the communicative environment in the educational process and cadets' cognitive activity (Bloshchynsky, 2015a; Willoughby \& Ibrahimov, 2014); by the implementation of interdisciplinary integration that is fulfilled by efforts consolidation of teachers delivering humanitarian, natural and scientific, and professional military subjects (common interdisciplinary projects, cadets preparing of reports that have interdisciplinary character, development of the system of interdisciplinary knowledge, conferences holding) (Jones-Kellogg \& Martin, 2018; Pet'ko, 2016).

A significant amount of free foreign language information that refers to all types of the military's professional work, which appeared as a result of impetuous development of the society and fast rates of its computerization, determines the necessity for future officers to deal with its amount independently, to find and estimate it adequately (for example, knowledge on the physical basis of building new samples of armament and military machinery produced abroad, the experience of their operation and implementation by allies and possible enemies, obtained from foreign informational sources, in particular in international military showrooms, exhibitions, joint exercises, competitions, and so on) (Blowers, 2017; Romanenko, 2016; Tyron, 2017). Permanent reference to various foreign-language sources of information enables to obtain, accumulate, and update knowledge.

Nowadays the language of cadets studying in higher military education establishments is full of scientific, technical, and special military terms, which they have to use during the educational process (Liu, 2014). Such kind of knowledge is also necessary to be used in the process of foreign language training given that a significant number of these special terms are international. Integrative objectives of foreign language training of future officers concerning the formation of communicative competence are as follows: formation of cadets' professional worldview depending on narrow specialization; development of qualities helping find efficient solutions in different situations taken from the practical operation; development of foreign language thinking activity and the special way of thinking based on the abilities to use necessary military and technical terms and notions in real professional work (Hošková-Mayerová, 2011).

Within the research, the organization of the educational process in higher military education establishments is focused on the improvement of foreign language training of future officers to form communicative competence. It has also been based on the realization of several patterns:

1) quality dependence of foreign language professional military training of future officers based on the communicative competency formation on the ideological provision of the military educational system operation;

2) material and financial cost allocated to military education: implementation of advances in science and technology into the educational process; highly technological information management; positive cadets' motivation for educational and professional activities (Graaf, 2014);

3) efficiency dependence of foreign language military and professional training of cadets based on the formation of 
communicative competence on actions unity of all subjects and the level of the personal activity of training subjects; conformity of foreign language training content to personal needs and needs of educational and professional activities; correlation, sequence, intersectionality and goals efficiency of subjects of all types and forms of engagement at each stage of foreign language training.

\section{Materials and Methods}

\subsection{Research Design}

Realization of the experiment involved creation of the scientifically grounded system of educational process organization aimed at development, checking, and generalization of new scientific hypotheses on ways to increase the efficiency of foreign language training of future officers with regard to the formation of communicative competence. The idea to organize a particular experiment always appears from the analysis and generalization of real problems taken from the practice of foreign language teaching while future officers training (Triakina, Pavlenko, Volkova \& Kassim, 2018). The person-oriented operative approach is mainly the basis of the experiment within the research. During the experiment, it stipulates the detection of foreign language training possibilities in the formation of communicative competence of future officers for various aspects along with a comprehensive assessment of its static and dynamic state taking into account alleged correlations between properties (Luchaninova, Koval, Deforzh, Nakonechna \& Golovina, 2017). The implementation of this approach is related to the humanistic paradigm of education that declares personality development as a goal of education (Uribe, LeLoup, Long \& Doyle, 2014). The key demand was a subject-oriented organization of cadets' educational activity within the experiment with the development of pedagogical tasks of varying complexity and problems. The main advantage of the person-oriented operative approach within the foreign language training of future officers was understanding of the fact that accomplishing of such tasks would contribute to the development of both subject (communicative) competence of future officers and their development as a personality (Waldvogel \& de Souza, 2017).

\subsection{Population Sampling}

In the organization of the pedagogical experiment, the essential task was to determine members of the researched object to provide a representative sampling. To provide validity and representativeness of pedagogical measurement and possibility to compare them, 52 cadets were divided into two groups similar in composition - experimental (EG) and control (CG) including 25 and 27 cadets accordingly (a quantitative difference is explained by the number of training platoons). CG was studying traditional teaching materials, while in EG, foreign language training was conducted based on the experimental methodology. Before the experiment, CG and EG were not different by the rate of communicative competency formation and were almost in equal conditions of the educational activity on the base of higher military education establishments.

\subsection{Description of a Training Program}

In the research, the most important principles of the development of communicative competence in future officers in the process of foreign language training included:

- the principle of consistency and continuity provided for the systematic acquisition of communicative competence in the process of foreign language training in classes and in various types of educational and professional activities, reflected the organic unity, interconnection and interdependence of the constituent elements of intercultural communicative competence;

- the principle of cadets' reflexivity invloves their expression of reflection and self-assessment in acquisition of intercultural communicative competence. The implementation of this principle in teaching involved a conscious attitude of the cadet to the process of learning and mastering the techniques of self-esteem and building independent work aimed at self-development and self-improvement;

- the principle of axiologization provided for the formation of value motivations and attitudes to language, intercultural communicative competence as an integrative professional and personal resource that affects intercultural interaction in both educational, professional, and socio-cultural spheres;

- the principle of cultural conformity provided for the relationship of the processes of formation of the culture of the cadet's personality and his intercultural communicative competence;

- the principle of individualization provided for maximum consideration of the level of abilities, development of personal potential of the cadet, his individuality;

- the principle of clarity provided for the representation of linguistic and extra-linguistic realities of the surrounding reality in accordance with the specifics of the perception of information by modern cadets with the use of innovative technologies. 
The implementation of the author's methodology of forming communicative competency of future officers in the process of foreign language training took place during 2017-2019 while studying the subject "Foreign language" within intercultural educational environment of Hetman Petro Sahaidachnyi National Ground Forces Academy, which covered four components (Figure 1): immersion, virtual, interactive, and discourse educational environments.

\begin{tabular}{|c|c|}
\hline $\begin{array}{l}\text { Immersion educational } \\
\text { environment }\end{array}$ & $\begin{array}{l}\text { - total immersion in the team } \\
\text { - cadets exchange programs } \\
\text { - presentation methods, self-assessment methods }\end{array}$ \\
\hline $\begin{array}{l}\text { Virtual educatioanl } \\
\text { environment }\end{array}$ & $\begin{array}{l}\text { - deliberative, training, and comparative methods } \\
\text { - methods of group cooperation in studying } \\
\text { - the method of independent assessment }\end{array}$ \\
\hline $\begin{array}{l}\text { Interactive educational } \\
\text { environment }\end{array}$ & $\begin{array}{l}\text { - establishing of virtual ties } \\
\text { - method of video conferences, method of } \\
\text { Internet-projects, learning in the virtual } \\
\text { environment } \\
\text { - method of expert assessment }\end{array}$ \\
\hline $\begin{array}{l}\text { Discourse educatioanl } \\
\text { environment }\end{array}$ & $\begin{array}{l}\cdot \text { military research work } \\
\cdot \text { military games, stimulation methods } \\
\cdot \text { matrix method, portfolio method }\end{array}$ \\
\hline
\end{tabular}

Figure 1. Types of intercultural educational environment components of Hetman Petro Sahaidachnyi National Ground Forces Academy to form communicative competence among future officers

Immersion environment was an environment where communication between communicators was done in their native language for some of them and in the foreign language for others. The basis of immersion was "immersion effect" reached by the total immersion based on the pedagogical technology of "total immersion." (Duong, 2014). The key elements of the immersion environment were a total immersion in the team, cadets exchange programs, presentation methods, and methods of self-assessment.

Virtual educational environment as an imitational analogue of the real educational or professional environment enabled to form and improve various professional and personal competences, particularly communicative competence of future officers while foreign language training in higher military education establishments. The virtual educational environment was built through the following methods: deliberative, training, comparative, group cooperation in studying, and the method of independent assessment.

Interactive educational environment was built based on a set of educational methods, the basis of which was a cooperation between participants of the educational process and an obligatory availability of feedback as a result of this cooperation. The key elements of the interactive environment were establishing virtual ties, method of video conferences, method of Internet-projects, learning in the virtual environment, and method of expert assessment.

Discourse educational environment involved a gradual transition (step by step) from one educational unit (a section in an educational program, an educational module, an educational theme, etc.) to another. Discourse educational environment was built with an emphasis on military research work, military games, stimulation methods, matrix method, and portfolio method.

The work in classes on the formation of communicative competence of future officers in the process of foreign language training was conducted in small groups (a group of officers of a command post, a group of information processing, etc.). It allowed all cadets to participate in the work, to practice skills of decision making, cooperation, interpersonal communication (a skill to listen actively, to build a mutual thought, to tackle emerging differences), and to stimulate their cognitive activity. The cooperation between cadets in a group and competition between groups were provided under such circumstances.

Foreign language training of future officers in terms of communicative competence formation was taking place based on implantation of informational and communicative technologies of teaching: Internet-technologies, in particular social services Web 2.0. It allowed searching for information, communicating at a distance (search systems, e-mails, and social networks), holding online video conferences and webinars (for example, Skype-technology), etc. 
The innovative method of forming the communicative competence of future officers in the process of foreign language training included the following stages:

Stage 1 - adaptive, which consisted in creating a motivational and stimulating background for the development of intercultural communicative competence of cadets of a military higher educational institution;

Stage 2 - the reproductive stage, which consisted in the formation of readiness to use intercultural communicative competence in professional activities;

Stage 3 - productive and creative, which consisted in the active creative application of intercultural communicative competence of future officers;

Stage 4 - reflexive, which consisted in the development and application of skills of self-analysis and self-assessment of their own intercultural communicative competence, as well as in determining the strategy and tactics of self-development of future officers in terms of intercultural communicative competence;

Stage 5-control and evaluation, which consisted in an external evaluation of the level of intercultural communicative competence of future officers. The valuation was carried out by the teaching staff, taking into account the specialization of cadets.

\section{Results}

Level formation assessment of communicative competence of future officers in the process of foreign language training at the pre-experimental and post-experimental stages of the research was held by using a practical analogical set of evaluative and diagnostic tools (an integrated test), procedures and methodologies (targeted monitoring, a set of adapted tests application, an online survey, a questionnaire, case-study, situational modeling, pedagogical reflection, individual and group interviews, statistical processing of data, etc.).

Forms and methods of control over the development of communicative competence of future officers in the process of foreign language training took into account the properties and features, which will be necessary for the graduates in their further professional activities. Peculiarities of control and assessment of foreign language communicative competence also included consideration of key areas of activity of future officers. Therefore, in addition to traditional tests, we used innovative forms of control, for example, solving professional problems by means of a foreign language.

The results of the experiment were processed by mathematical statistics methods. In particular, we used the comparison method of two independent samplings - criterion $\chi^{2}$ and calculated statistical features of grades for an integrated test. We determined:

- a sample mean score: $\bar{x}=\frac{1}{n} \sum_{i=1}^{k} x_{i} n_{i}$, where $x_{i}$ - a grade for an integrated test, $n_{i}$ - frequency of the relevant grade occurrence in the sampling;

- dispersion: $D=\frac{1}{n} \sum_{i=1}^{n}\left(x_{i}-\bar{x}\right)^{2} \cdot n_{i}$;

- mean square deviation: $\sigma=\sqrt{D}$;

- density of grades according to the three sigma rule: $m=(\bar{x}+2 \sigma)-(\bar{x}-2 \sigma)$.

At the beginning of the experiment, a comparison of students' division according to their level of educational achievements was conducted (Table 1). The aim of this statistical operation is to confirm the insignificant difference between educational achievements in mastering communicative competence of students from both groups (see Figures 2-4).

To check the null hypothesis $\left(H_{0}\right)$ that there is not any difference between the division of students from both groups according to the level of their educational achievements we used criterion $\chi^{2}$ (Table 2). 
Table 1. The formation level of future officers' communicative skills before and after the experiment

\begin{tabular}{ccccccccc}
\hline \multirow{2}{*}{$\begin{array}{c}\text { Level of } \\
\text { knowledge }\end{array}$} & \multicolumn{3}{c}{ Before the experiment } & \multicolumn{3}{c}{ After the experiment } \\
\cline { 2 - 9 } & \multicolumn{2}{c}{ CG (27 cadets) } & EG (25 cadets) & CG (27 cadets) & EG (25 cadets) \\
\cline { 2 - 9 } & Number & $\%$ & Number & $\%$ & Number & $\%$ & Number & $\%$ \\
\hline Creative & 3 & $11,11 \%$ & 2 & $8 \%$ & 2 & $7,41 \%$ & 10 & $40 \%$ \\
Reconstructive & 9 & $33,33 \%$ & 10 & $40 \%$ & 11 & $40,74 \%$ & 12 & $48 \%$ \\
Reproductive & 11 & $40,74 \%$ & 9 & $36 \%$ & 11 & $40,74 \%$ & 3 & $12 \%$ \\
Identification & 4 & $14,82 \%$ & 4 & $16 \%$ & 3 & $11,11 \%$ & 0 & $0 \%$ \\
\hline
\end{tabular}

$\%$

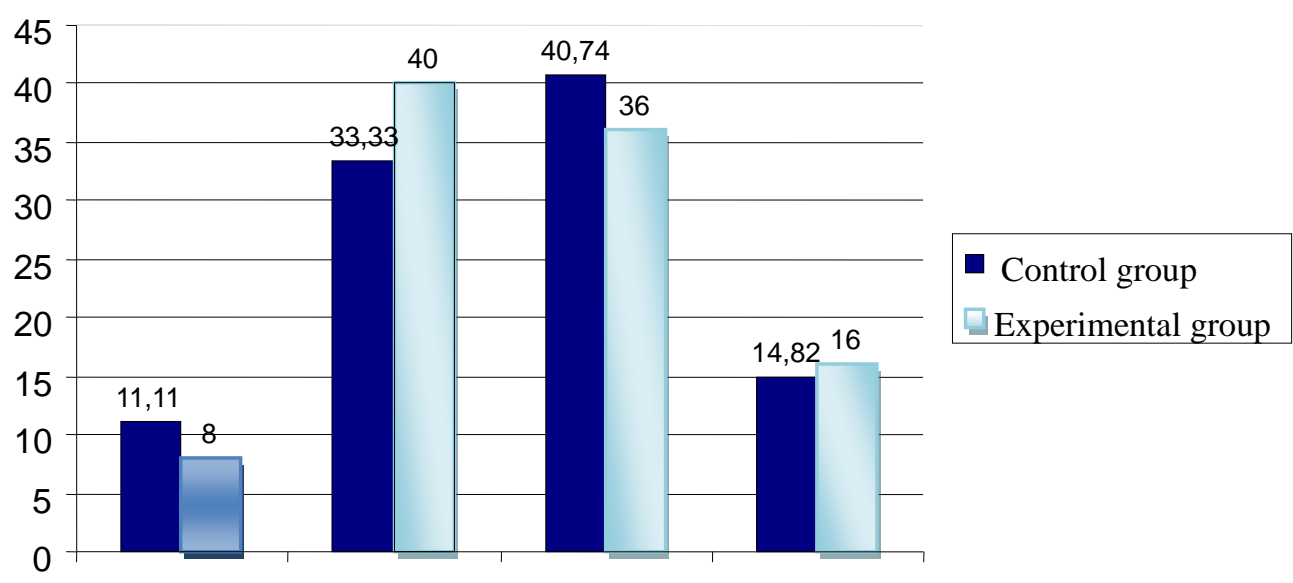

Creative Reconstructive Reproductive Identification

Figure 2. The level of proficiency in communicative competence of future officers in the process of foreign language training before the experiment

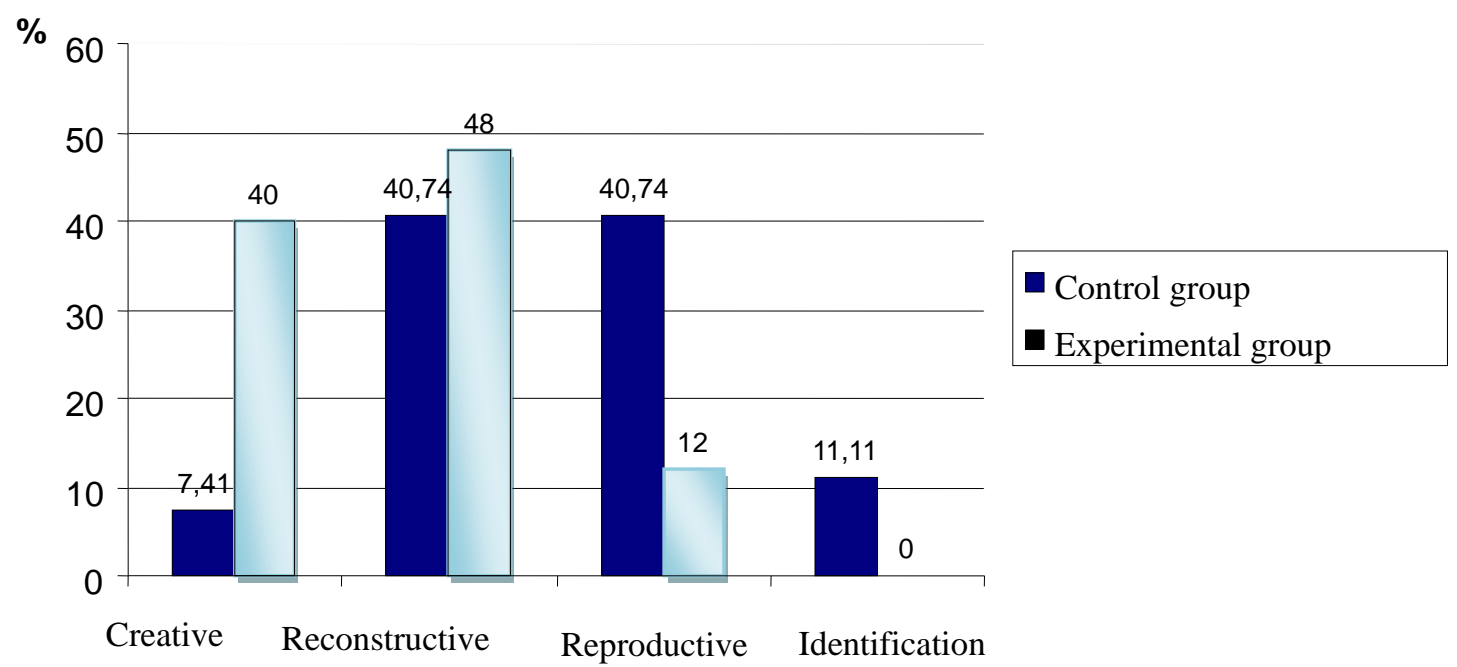

Figure 3. The level of proficiency in communicative competency of future officers in the process of foreign language training after the experiment 


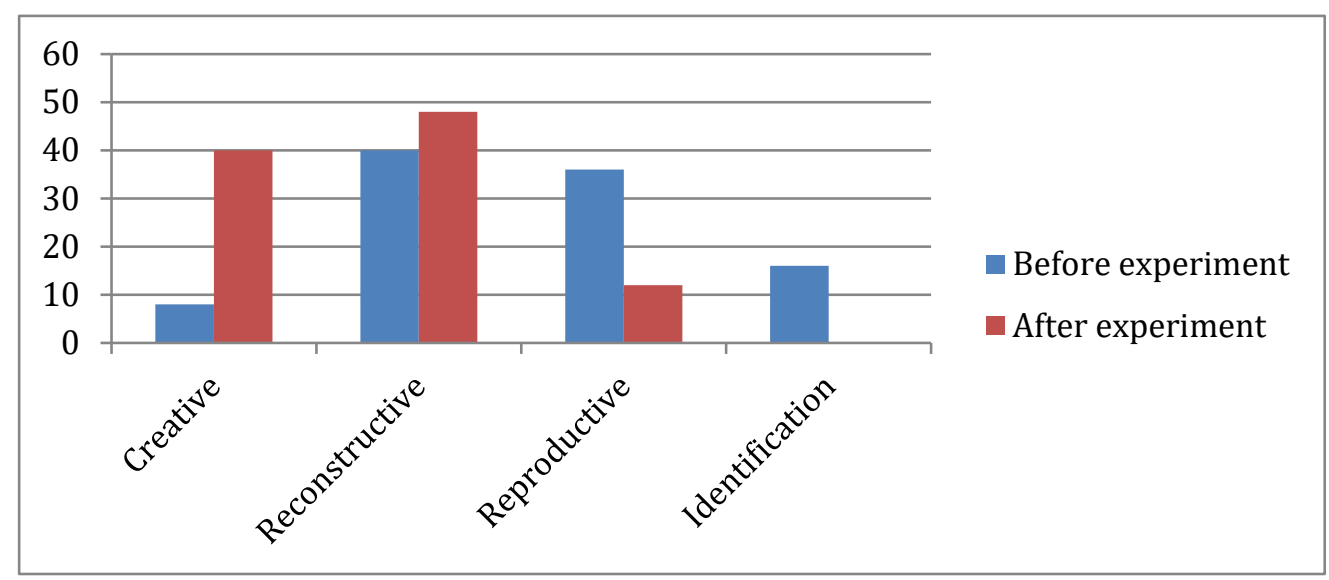

Figure 4. The level of proficiency in communicative competency of future officers in the process of foreign language training in the experimental group before and after the experiment

Table 2. Calculation of the criterion $\chi^{2}$ for the groups under study at the beginning of the experiment

\begin{tabular}{|c|c|c|c|c|c|}
\hline \multirow{2}{*}{$\mathrm{N}$} & \multicolumn{2}{|c|}{ Frequencies } & \multirow{2}{*}{$f_{1} \cdot f_{1}$} & \multirow{2}{*}{$f_{1}+f_{2}$} & \multirow{2}{*}{$\frac{f_{1} \cdot f_{1}}{f_{1}+f_{2}}$} \\
\hline & $f_{1}$ & $f_{2}$ & & & \\
\hline 1 & 3 & 2 & 9 & 5 & 1.8 \\
\hline 2 & 9 & 10 & 81 & 19 & 4.26 \\
\hline 3 & 11 & 9 & 121 & 20 & 6.05 \\
\hline 4 & 4 & 4 & 16 & 8 & 2 \\
\hline$\sum$ & 27 & 25 & & & 14.11 \\
\hline
\end{tabular}

As the number of elements is the same in samplings, we will use a formula (McClarty, Way, Porter, Beimers \& Miles, 2013):

$$
\chi_{\text {emp }}^{2}=\frac{\mathrm{N}^{2}}{\mathrm{n}_{1} \cdot \mathrm{n}_{2}} \cdot\left(\sum_{\mathrm{i}=1}^{\mathrm{n}} \frac{\mathrm{f}_{1} \cdot \mathrm{f}_{1}}{\mathrm{f}_{1}+\mathrm{f}_{2}}-\frac{\mathrm{n}_{1} \cdot \mathrm{n}_{1}}{\mathrm{~N}}\right)
$$

where $N$ - number of elements in each sampling, $f_{1}$ and $f_{2}-$ frequencies of the first and second samplings accordingly.

Based on the formula given above, we have $\chi_{e m p}^{2}=\frac{52^{2}}{27 \cdot 25} \cdot\left(14,11-\frac{27 \cdot 27}{52}\right)=0,361$. A number of will's levels is determined by the formula $v=(k-1) \cdot(c-1)$ where $k$-a number of indication categories, $c$-a number of samplings. In our case, $k=4$ and $c=2$. Thus, $v=(4-1) \cdot(2-1)=3$. Based on the tables of crucial values $\chi^{2}$ we find:

$$
\chi_{c r}^{2}=\left\{\begin{array}{l}
7,815 \text { for } \mathrm{P} \leq 0,05 \\
11,345 \text { for } P \leq 0,01
\end{array}\right.
$$

Build "the axis of importance" (Figure 5): 


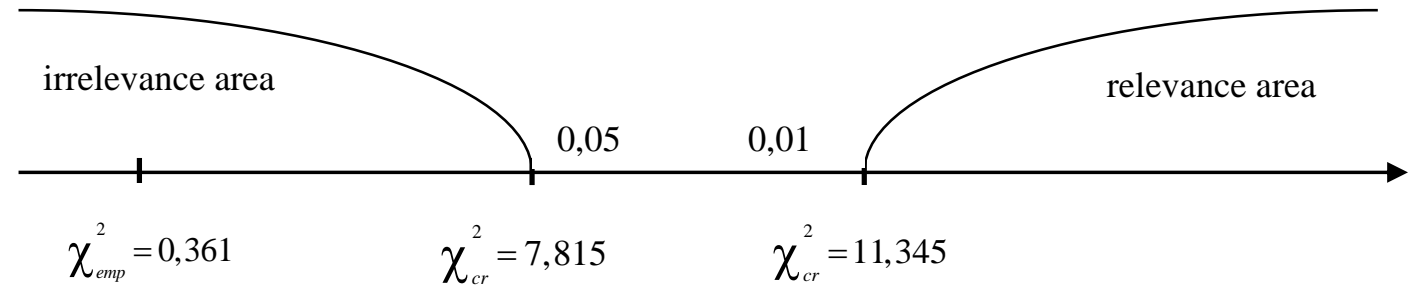

Figure 5. The axis of importance

The empirical value $\chi_{e m p}^{2}$ fell into the zone of unimportance. Thus, the hypothesis $\mathrm{H}_{0}$ that there are not any differences between the division of students in both groups according to the level of their educational achievements at the beginning of the experiment is accepted.

After the experiment, comparison of control and experimental groups divisions according to the level of their educational achievements in mastering communicative competence of future officers in the process of foreign language training was conducted one more time. In this case, hypothesis are as follows:

$H_{0}$ - empirical divisions of EG and CG according to the level of educational achievements in formation after the experiment are different;

$H_{l}$ - empirical divisions of EG according to the level of educational achievements in mastering communicative competence of future officers in the process of foreign language training at the beginning and at the end of the experiment are different.

Calculations on the criterion $\chi^{2}$ are represented in Tables 3 and 4.

Table 3. Calculation of the criterion $\chi^{2}$ for the groups under study after the experiment

\begin{tabular}{lllllll}
\hline \multirow{2}{*}{$\mathrm{N}$} & \multicolumn{2}{c}{ Frequencies } & \multicolumn{2}{l}{$f_{1} \cdot f_{1}$} & $f_{1}+f_{2}$ & $\frac{f_{1} \cdot f_{1}}{f_{1}+f_{2}}$ \\
\cline { 2 - 3 } & $f_{1}$ & $f_{2}$ & 4 & 12 & 0.33 \\
\hline 1 & 2 & 10 & 121 & 23 & 5.26 \\
2 & 11 & 12 & 121 & 14 & 8.64 \\
3 & 11 & 3 & 9 & 3 & 3 \\
4 & 3 & 0 & & & 17.23 \\
$\Sigma$ & 27 & 25 & & & \\
\hline
\end{tabular}

Table 4. Calculation of the criterion $\chi^{2}$ for the experimental group

\begin{tabular}{cccccc}
\hline & \multicolumn{2}{c}{ Frequencies } & & $f_{1} \cdot f_{1}$ & $f_{1} \cdot f_{1}$ \\
\cline { 2 - 3 } & $f_{1}$ & $f_{2}$ & & & $f_{1}+f_{2}$ \\
\hline 1 & 2 & 10 & 4 & 12 & 0.33 \\
2 & 10 & 12 & 100 & 22 & 4.55 \\
3 & 9 & 3 & 81 & 12 & 6.75 \\
4 & 4 & 0 & 16 & 4 & 4 \\
\hline$\sum$ & 25 & 25 & & & 15.63 \\
\hline
\end{tabular}

By using the formula given above, we have:

$$
\chi_{\text {emp }}^{2}=\frac{52^{2}}{27 \cdot 25} \cdot\left(17,23-\frac{27 \cdot 27}{52}\right)=12,86
$$

A number of will's level $v=(k-1) \cdot(c-1)=(4-1) \cdot(2-1)=3$. According to the table of crucial values $\chi^{2}$, we got (Figure 6): 


$$
\chi_{c r}^{2}=\left\{\begin{array}{l}
7,815 \text { for } \mathrm{P} \leq 0,05 \\
11,345 \text { for } P \leq 0,01
\end{array}\right.
$$

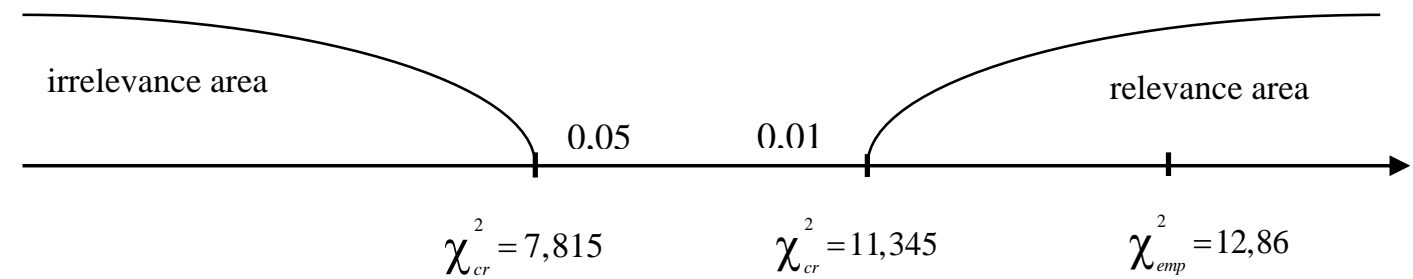

Figure 6. The axis of importance

$\chi_{e m p}^{2}$ is in the zone of importance. Thus, the hypothesis $H_{0}$ is accepted. It states that empirical divisions of experimental and control groups according to the level of educational achievements in mastering communicative competence of future officers in the process of foreign language training at the end of the experiment are different.

As a number of elements in samplings are the same, we will use the formula:

$$
\chi_{e m p}^{2}=4 \cdot \sum_{i=1}^{n} \frac{f_{1} \cdot f_{1}}{f_{1}+f_{2}}-2 N
$$

where $N$-a number of elements in each sampling, $f_{1}$ and $f_{2}$ - frequencies of the first and second samplings accordingly. According to the formula (1), we got:

$$
\chi_{e m p}^{2}=4 \cdot 15,63-2 \cdot 25=12,52 .
$$

A number of will's levels $v=(k-1) \cdot(c-1)=(4-1) \cdot(2-1)=3$. According to the table of crucial values $\chi^{2}$, we have (Figure 7):

$$
\chi_{c r}^{2}=\left\{\begin{array}{l}
7,815 \text { for } \mathrm{P} \leq 0,05 \\
11,345 \text { for } P \leq 0,01
\end{array}\right.
$$

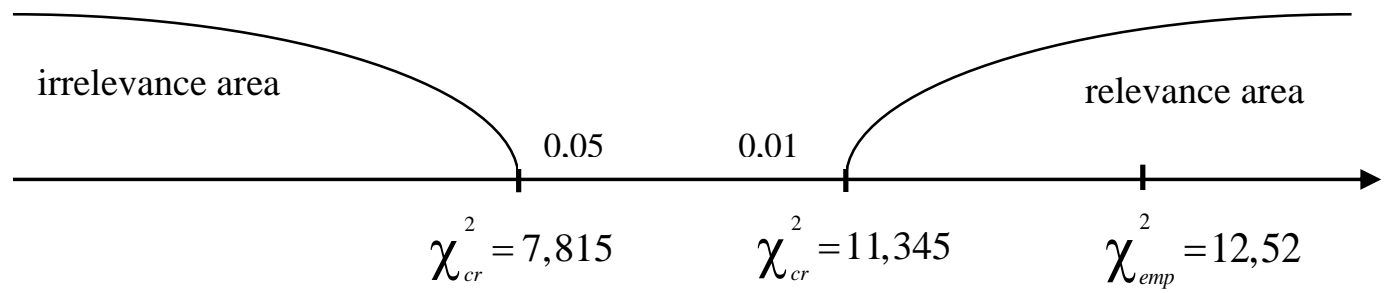

Figure 7. The axis of importance

As $\chi_{e m p}^{2}$ is in the zone of importance, we accept the hypothesis $\mathrm{H}_{1}$ that empirical divisions of the experimental group according to the level of educational achievements in mastering communicative competence of future officers in the process of foreign language training at the beginning and at the end of the experiment are different. Also, the calculation of statistical features of grades for an integrated test at the beginning and at the end of the experiment was conducted (Tables 5 and 6).

Table 5. Statistical processing characteristic of academic records at the beginning of the experiment

\begin{tabular}{lll}
\hline Characteristic & Control Group & Experimental Group \\
\hline Sample mean & 3.41 & 3.40 \\
Dispersion & 0.76 & 0.72 \\
Mean square deviation & 0.87 & 0.85 \\
Grades density & $5.15-1.67$ & $5.1-1.7$ \\
\hline
\end{tabular}


Table 6. Statistical processing characteristic of academic records after the experiment

\begin{tabular}{lll}
\hline Characteristic & Control group & Experimental group \\
\hline Sample mean & 3.44 & 4.28 \\
Dispersion & 0.62 & 0.52 \\
Mean square deviation & 0.8 & 0.72 \\
Grades density & $5.04-1.84$ & $5.72-2.84$ \\
\hline
\end{tabular}

Thus, the analysis of Tables 5 and 6 prove that grade point average (GDA) of mastering communicative competence of future officers in the process of foreign language training has increased in the experimental group. It is regarded as the index in favour of the suggested methodology. The mean square deviation for the experimental group has decreased, meaning that grade dispersion has also decreased with regard to GDA.

The experimental implementation of the developed methodology of forming communicative competence of future officers in the process of foreign language training enabled to reach the following results: quantity of cadets with the creative level of formation increased from $8 \%$ to $40 \%$ in EG; with reconstructive level - from $40 \%$ to $48 \%$; regarding the reproductive level, the number of future officers with this level of formation decreased from $36 \%$ to $12 \%$; at the identification level - from $16 \%$ to $0 \%$.

An additional factor that determined the efficiency of the developed methodology is its positive recognition by cadets. Participants of the survey stated that their interest in intercultural communication, their profession, and the work with authentic texts that enable them to get actual professional military information in a foreign language had increased. Cadets mentioned the experience in the active creative implementation of the communicative competence of cadets from higher military education establishments. Besides, cadets from EG pointed that they were interested in the possibility to conduct the analysis of similarities and differences in cultures and military systems of different countries and Ukraine. It enabled them to interpret events that were happening in both their native country and abroad. Such a positive assessment is regarded as a motivation stimulus to intercultural communication and as a prerequisite to forming a high level of professional foreign language activity among future officers.

\section{Discussion}

The increase of international and cross-national contracts resulted in not treating future officers apart from the informational environment, which is developing too fast (DeKay, 2012; Sergeeva, 2014). In this situation, the problem of quality improvement of foreign language training for future officers focusing on its practical realization in everyday professional work has become particularly important. In modern terms of military service performance due to the appearance of an innovative, changeable, multilingual, and multicultural environment, an officer has to use a foreign language, obtain necessary information in a foreign language independently, implement it, and solve problems of further foreign language development.

Foreign language teaching in higher military education establishments is professionally oriented, integrated to the special subjects, and built taking into account cadets' needs that are determined by the future profession (Jaros, 2018). Thus, the basis of cadets' independence formation is military-technical and military-scientific texts (Pulverness, Klimova, Kalugina, Vasbieva \& Ismagilova, 2017; Yang, 2015). The main goal of the professional military text is to obtain, analyse, generalize, and implement the information in a foreign language in the practice as well as repetition of the language material by cadets for many times.

The end result and indicator of the quality of foreign language education is the positive dynamics of the development of communicative competence of future officers, which allows them to carry out productive professional activities in different situations of intercultural and business communication based on a set of language skills, including: foreign language lexicon expressions; correct application of knowledge of grammar rules; adaptation to numerous linguistic, social, cultural and professional norms in the context of interactive communication.

The study is consistent with the conclusions of Romanenko (2016) that a military specialist should not only have a good command of the basic language, but also have information about specific areas of vocabulary (military translation, medical and legal vocabulary); have knowledge in the field of military terminology; have knowledge about the country (in particular, about the political system, religion, culture, history); know the nature of combined action; know the organizational and staffing structure of both their troops and enemy troops; be ready for translation in difficult combat and climatic conditions. 
The author's experimental methodology implementation broadens possibilities of the intercultural educational environment of higher military education establishments, provides the realization of a linguistic component of the foreign language training content of future officers. Comparing cadets from EG and those form CG, significant progress in mastering special professional military vocabulary and language structures, general cultural and culturally specific tasks, behavioural strategies and communicative language skills, professionally and military important language skills and abilities is emphasized. They obtained solid skills in overcoming cultural barriers, stress situations, and "cultural shock." In addition, they learned how to adapt to life in the foreign language environment and gained experience in intercultural professional military communication in real terms of communication.

\section{Conclusion}

Communicative competence of future officers is a basic element of professional competence, and it identifies the commanding officer's ability to control his subordinates in various service and military situations, to transfer and receive effectively the necessary information, in particular in a foreign language. The development of modern multicultural, linguistic and information environment is determined by significant accessibility of the information in a foreign language. It actualized the problem of communicative competence and the readiness of future officers to organize independently an orderly and effective cooperation with this environment in future professional work. The foreign language training of future officers is the process of establishment and development of a complex integral personal formation that enables to implement foreign language knowledge as a means for professional self-realization and self-development. Improvement of foreign language training is focused on the formation and development of a linguistic personality of cadets from higher military education establishments who can carry out independently communicative activities in the integrated multicultural environment, work independently with the information in the system of non-native linguistic culture and use it for personal and professional purposes.

It has been determined that the use of possibilities of the intercultural educational environment in higher military education establishments as a set of immersive, virtual, interactive, and discourse educational environments has a significant potential for providing the quality of foreign language training and increasing the level of communicative competence of future officers based on the continuously operating, direct and inverse relations between the educational departmental system and cadets; changes in a teacher's role as an organizer of the educational process and a consultant at the same time; relations between a teacher and cadets, which are happening both directly and indirectly through the academic group, a computer, a local net, etc.

It has also been identified that the implementation of the author's experimental methodology provides "unobtrusively-obligatory" activation of cadets' cognitive activity, their involvement in the active work based on self-tuition. The research has fixed a moderate impact of the methodology implementation on the cadets' activity on the search for the solvation of the intercultural communication problem at a high level of effort.

The developed methodology is unique because it enables to form not only communicative competence within foreign language training of future officers simultaneously based on a set of interdependent elements: goals, principles, models of the educational environment, the content of subjects (based on the inter-subject integration of technical and special subjects as well as a foreign language), and formation stages. It can also be used for developing other types of competences and the further improvement of professional military training of cadets and the modernization of the whole educational and methodological process in higher military education establishments. The developed methodology can be used successfully in the practice of foreign language teaching in other higher military education establishments as well as in the creation of teaching materials (textbooks, training manuals, methodological recommendations) for foreign language learning.

The further research involves thorough development of methods and techniques of the culture-oriented linguistic approach during professional foreign language training of cadets and students of non-language higher education institutions, and extension of the application field of the suggested methodology. Foreign language training of cadets, provided improvement of its organizational, pedagogical and methodological support, can make a real contribution to solving the urgent problem - the formation of a high level of communicative competence of future officers of the Armed Forces of Ukraine.

\section{Limitations and Suggestions}

The research has identified a number of problems, which need further study, including improvement of professional foreign language communicative skills of officers during their professional work; the possibility to implement psychological and pedagogical training courses to overcome communicative barriers in the career development 
system. In our view, perspective directions of further scientific research can be as follows: clarification of teaching content in forming the culture of foreign language communication; improvement of methods and forms of communicative competence in the process of foreign language training of future officers; continuity establishment in the formation of foreign language communicative competence of future officers with the further stages of postgraduate skills development. Besides, the suggested methodology can be successfully used in the process of different specialists training because its main strategic direction is to form skills for intercultural communication among students.

\section{References}

Besnier, N. (2013). Language on the edge of the global: Communicative competence, agency, and the complexity of the local. Language \& Communication, 33(4), 463-471. https://doi.org/10.1016/j.langcom.2013.02.002

Bloshchynskyi, I. (2015a). Characteristics of personnel distance learning platforms possibilities in the State Border Guard Service of Ukraine. The Advanced Science Journal, 4, 77-81. https://doi.org/10.15550/ASJ.2015.04.077

Bloshchynskyi, I. (2015b). Methods of distance learning of personnel in the State Border Guard Service of Ukraine. Central European Journal for Science and Research, 2(15), 27-34.

Blowers, E. M. (2017). Towards a multilingual and cross-cultured officer corps: A study of language and culture training programs for army ROTC cadets. Master's Thesis. Syracuse University, Syracuse, NY.

Crouse, D. (2018). Languages for specific purposes in the 21st century. The Language Educator, 8(3), 32-35.

DeKay, S. H. (2012). Interpersonal communication in the workplace: A largely unexplored region. Business Communication Quarterly, 75(4), 449-452. https://doi.org/10.1177/1080569912458966

Duong, T. M. (2014). An investigation into effects of role-play in an EFL speaking course. Global Journal of Foreign Language Teaching, 4(2), 81-91.

Graaf, M. (2014). Communication, integral to the achievements of the European Union Customs Union. WCO News, 73, 24-25.

Grin, F., \& Faniko, K. (2012). Foreign language skills and intercultural abilities: Operationalization with a large population. Management \& Avenir, 55(5), 168-184. https://doi.org/10.3917/mav.055.0168

Hackman, M. Z., \& Johnson, C. E. (2013). Leadership: A communication perspective, 6th ed. Long Grove, IL: Waveland Press.

Hošková-Mayerová, Š. (2011). "Operational program, education for competitive advantage", preparation of study materials for teaching in English. Procedia - Social and Behavioral Sciences, 15, 3800-3804. https://doi.org/10.1016/j.sbspro.2011.04.376

Hošková-Mayerová, Š. (2014). The effect of language preparation on communication skills and growth of students' self-confidence. Procedia - Social and Behavioral Sciences, 114, 644-648. https://doi.org/10.1016/j.sbspro.2013.12.761

Jaros, M. (2018). Leadership and methodology challenges in higher education: Integrating personal development, skills and competences in the space of digital systems. Global Journal of Information Technology, 4(1), 01-06.

Jones-Kellogg, R. L., \& Martin, S. (2018). Portuguese as a world language for future army officers. Hispania, 100(5), 295-296. https://doi.org/10.1353/hpn.2018.0071

Koval, V., Polyezhayev, Y., \& Bezkhlibna, A. (2018). Communicative competences in enhancing of regional competitiveness in the labour market. Baltic Journal of Economic Studies, 4(5), 105-113. https://doi.org/10.30525/2256-0742/2018-4-5-105-113

Liu, R.-Z. (2014). On ideological education of border-control forces of public security guided by service function. Journal of Chinese People's Armed Police Force Academy, 11, 53-56.

Luchaninova, O., Koval, V., Deforzh, H., Nakonechna, L., \& Golovina, O. (2017). Formation of communicative competence of future specialists by means of group work. Espacios, 40(41), 11-18.

McClarty, K. L., Way, W. D., Porter, A. C., Beimers, J. N., \& Miles, J. A. (2013). Evidence-based standard setting: establishing a validity framework for cut scores. Educational Researcher, 42(2), 78-88. https://doi.org/10.3102/0013189X12470855 
Mikkelson, A. C., York, J. A., \& Arritola, J. (2015). Communication competence, leadership behaviors, and employee outcomes in supervisor-employee relationships. Business and Professional Communication Quarterly, 78(3), 336-354. https://doi.org/10.1177/2329490615588542

Pet'ko, L. V. (2016).Teaching methods and the formation of professionally oriented foreign language learning environment in conditions of university. Intellectual Archive, 5(4), 73-87.

Pulverness, A., Klimova, I. I., Kalugina, O. A., Vasbieva, D. G., \& Ismagilova, L. R. (2017). The formation of students' intercultural communicative competence in an English language learning environment at a non-linguistic higher school. XLinguae, 10(4), 381-397. https://doi.org/10.18355/XL.2017.10.04.31

Robles, M. M. (2012). Executive perceptions of the top 10 soft skills needed in today's workplace. Business Communication Quarterly, 75, 453-465. https://doi.org/10.1177/1080569912460400

Romanenko, Y. O. (2016). Place and role of communication in public policy. Actual Problems of Economics, 2(176), 25-31.

Sergeeva, N. N. (2014). Foreign language communicative competence in the field of professional activity: model and method development. Procedia - Social and Behavioral Sciences, 154, 250-253. https://doi.org/10.1016/j.sbspro.2014.10.145

Triakina, O., Pavlenko, O., Volkova, N., \& Kassim, D. (2018). Usage of E-learning tools in self-education of government officers involved in global trade activities. Proceedings of the 1st International Workshop on Augmented Reality in Education, 173-181. Kryvyi Rih National University, Kryvyi Rih, Ukraine

Tyron, O. (2017). Psycholinguistic Approach to the foreign language competence formation of future seafarers. Psychology, 8(4), 663-675. https://doi.org/10.4236/psych.2017.84043

Umairah, N. (2014). Identifying the English and study skill needs of science students at the university: A case study. Cypriot Journal of Educational Sciences, 9(3), 203-229.

Uribe, D., LeLoup, J. W., Long, S. S., \& Doyle, M. S. (2014). Spanish at the United States Air Force Academy: Developing leaders of character as an LSP curricular model. Cuadernos de ALDEEU, 28, 188-221.

Waldvogel, D. A., \& de Souza, D. A. S. (2017). Brazil's rise and Portuguese as a strategic foreign language: preparing tomorrow's military leaders. Hispania, 100, 289-294. https://doi.org/10.1353/hpn.2018.0070

Willoughby, M. L., \& Ibrahimov, M. (2014). Army language, regional expertise, and culture program. Military Intelligence Professional Bulletin, 40(3), 12-21.

Yang, H. (2015). On the immigration inspection teaching-reform oriented on practical teaching and competitive training. Journal of Chinese People's Armed Police Force Academy, 7, 63-66. 